\title{
CITAC Award 2010: Three Most Interesting Papers in Metrology in Chemistry
}

Every year the Cooperation on International Traceability in Analytical Chemistry (CITAC) draws attention to three remarkable papers. The selection is based on nominations and balloting. The three award winning articles of the 2010 campaign are

- Takeshi Saito, Toshihide Ihara, Masayoshi Koike, Shinichi Kinugasa, Yoshinori Fujimine, Kazutoshi Nose and Tetsuya Hirai.

A new traceability scheme for the development of international system-traceable persistent organic pollutant reference materials by quantitative nuclear magnetic resonance.

Accred Qual Assur (2009) 14(2):79-86

- Garritt L Page and Stephen B Vardeman.

Using Bayes methods and mixture models in interlaboratory studies with outliers.

Accred Qual Assur (2010) 15(7):379-389

- Cristian G Arsene, André Henrion, Nina Diekmann, Jenny Manolopoulou and Martin Bidlingmaier.

Quantification of growth hormone in serum by isotope dilution mass spectrometry.

Anal Biochem (2010) 401(2):228-35; Epub 2010 Mar 10
Congratulations all winning authors! The diploma will be handed over during the next CITAC member's meeting in early April in Paris.

For the competition in a given year, papers should be nominated with an abstract (in English) and a supporting letter from a CITAC member before 1 September. Then all CITAC members are informed and called upon to give their votes for the three most appropriate papers. The results are published on the CITAC website at http://www.citac.cc, in CITAC News and in Accreditation and Quality Assurance as well as in other publications.

CITAC invites all colleagues from the metrology and analytical chemistry communities to support the nomination process by submitting proposals to the CITAC members (listed on the above mentioned website).

(source: CITAC Secretariat, philippe.charlet@lne.fr; 29 November 2010) 